Krzysztof Zawacki

(Archiwum Państwowe w Poznaniu)

mgr, kzawacki@poznan.ap.gov.pl

ORDCID iD: 0000-0001-9547-7490

\title{
Archiwum Państwowe w Poznaniu w latach 1939-1945
}

\section{Organizacja}

Po wkroczeniu do Poznania armii niemieckiej 10 września 1939 r. zarząd nad Archiwum Państwowym w Poznaniu przejął dr Alfred Lattermann, który w okresie okupacji hitlerowskiej sprawował funkcję dyrektora Biblioteki Uniwersyteckiej. Szybko jednak nastąpiła zmiana opiekuna poznańskiej placówki. Został nim, z upoważnienia Wehrmachtu, wojskowy radca archiwalny (Heeresarchivrat) Danz z Berlina, który wydał rozkaz zewidencjonowania akt dotyczących b. pruskiego Generalkommando V w Poznaniu, a następnie wywiezienia około 7500 jednostek do Archiwum Wojskowego (Heeresarchiv) w Berlinie ${ }^{2}$.

Pod koniec września 1939 r. do Poznania powrócili dyrektor Kazimierz Kaczmarczyk oraz kustosz Adam Kaletka. Natychmiast zostali oni skierowani na przesłuchanie do miejscowego Gestapo, a następnie aresztowani i osadzeni w więzieniu przy ulicy Młyńskiej. Wielokrotnie przesłuchiwani w obecności obersturmführera Hardera i wojskowego radcę archiwalnego Danza. W końcu 2 października 1939 r. zostali zwolnieni, ale w zamian za to musieli wypakować ze skrzyń archiwalia, których nie wywieziono przed rozpoczęciem wojny, oraz przygotować wykaz ewakuowanych akt ${ }^{3}$.

${ }^{1}$ Artykuł jest częścią pracy magisterskiej Krzysztofa Zawackiego pt. „Reichsarchiv Posen w latach 1939-1945" napisanej pod kierunkiem prof. Krzysztofa Stryjkowskiego, która została obroniona w $2017 \mathrm{r}$.

${ }^{2}$ K. Kaczmarczyk, Archiwum Państwowe w Poznaniu w czasie okupacji niemieckiej, „Archeion” 1948, t. 17, s. 86 .

${ }^{3}$ Tenże, Adam Henryk Kaletka (1887-1956), „Archeion” 1956, t. 26, s. 322. 
17 października 1939 r. do Archiwum Państwowego w Poznaniu przybyli asesor archiwalny dr Hans Götting i dyrektor Archiwum Państwowego we Wrocławiu dr Erich Randt, którzy byli reprezentantami Generalnej Dyrekcji Pruskich Archiwów Państwowych. W obecności wojskowego radcy archiwalnego Danza, dyrektora Kaczmarczyka oraz kustosza Kaletki sporządzili protokół z kontroli stanu poznańskiej placówki archiwalnej oraz dokumentów wywiezionych na początku września w głąb kraju. W raporcie tym ustalono, że budynek archiwum nie uległ zniszczeniu podczas prowadzonych działań wojennych. Kazimierz Kaczmarczyk stwierdził, iż poza trzynastoma skrzyniami $\mathrm{z}$ archiwaliami i repertoriami nie wywieziono żadnej dokumentacji do innych urzędów, archiwów czy osób prywatnych. Poza tym zdecydowano się umieścić tymczasowo w magazynach dokumenty, akta, mapy i książki, które pozostały na miejscu, a także tę część materiałów, które - deportowane we wrześniu 1939 r. - miały wrócić do Poznania. Podjęto decyzję o przekazaniu kluczy do budynku archiwum wojskowemu radcy archiwalnemu Danzowi, ale tylko do czasu przybycia nowego niemieckiego kierownika tej instytucji. Wszystkie pomieszczenia służbowe i magazynowe miały zostać zamknięte, oprócz tych, które wykorzystano do skatalogowania akt wojskowych przeznaczonych do ewakuacji w głąb Rzeszy. Natomiast polskim pracownikom poznańskiego archiwum zakomunikowano, że otrzymają wynagrodzenia za swoją pracę, ale tylko do 30 września 1939 r., tłumacząc zaistniałą sytuację brakiem pieniędzy ${ }^{4}$.

Zadaniem dr. Hansa Göttinga oraz dr. Eicha Randta była organizacja niemieckiej służby archiwalnej na obszarach włączonych do Rzeszy. W ramach wypracowanego planu przewidziano m.in. wyznaczenie niemieckich archiwistów na kierowników poszczególnych placówek archiwalnych. Generalny Dyrektor Pruskich Archiwów Państwowych i dyrektor Archiwum Rzeszy w Poczdamie dr Ernst Zipfel wysunął kandydaturę dr. Hermanna Golluba, radcę archiwalnego (Archivrat) z Wrocławia, na stanowisko kierownika Archiwum Państwowego w Poznaniu. W stolicy Wielkopolski tenże pojawił się 27 października 1939 r., wraz z oddelegowanym do pracy w tutejszym Archiwum dr. Kurtem Forstreuterem z Archiwum Państwowego w Królewcu, który po krótkim okresie działalności powrócił do Królewca ${ }^{5}$. Na początku stycznia $1940 \mathrm{r}$. na jego miejsce przybył inny pracownik Archiwum Państwowego z Królewca, radca archiwalny dr Erich Sandow ${ }^{6}$, który 1 kwietnia 1940 r. został kierownikiem Archiwum Państwowego w Poznaniu, po

${ }^{4}$ Archiwum Państwowe w Poznaniu (dalej: AP Poznań), Namiestnik Rzeszy w Okręgu Kraju Warty - Poznań (dalej: RSH), sygn. 756, s. 4-5.

${ }^{5}$ D. Matelski, Grabież i restytucja polskich dóbr kultury: od czasów nowożytnych do czasów wspótczesnych, t. 1, Kraków 2006, s. 339.

${ }^{6}$ AP Poznań, Archiwum Rzeszy w Poznaniu (dalej: Archiwum Rzeszy), sygn. 210, s. 5. 
tym jak dr. Hermanna Golluba przeniesiono do Szczecina ${ }^{7}$. Swoją funkcję pełnił do końca stycznia 1942 r., ponieważ od 1 lutego 1942 r. zastąpił go na tym stanowisku wyższy radca archiwalny (Oberarchivrat) dr Erich Weise pełniący obowiązki kierownika archiwum do zakończenia okresu okupacji ${ }^{8}$.

W tym miejscu należałoby dodać, że przełożony Archiwum w Poznaniu nosił tytuł kierownika, a nie - jak w innych niemieckich instytucjach tego typu dyrektora. Dr Hermann Gollub, gdy zauważył powyższy problem, 24 marca 1941 r. złożył na ręce Namiestnika Rzeszy Kraju Warty (Reichsstatthalter Wartheland) pismo, przedstawiając w nim argumenty za przywróceniem funkcji dyrektora. Odwołał się m.in. do historii, a konkretnie do czasów pruskich, kiedy Archiwum Państwowe w Poznaniu znajdowało się pod niemieckim zarządem, a jego przełożonym był wtedy dyrektor. Zwrócił również uwagę na zmniejszenie renomy placówki, która - podobnie jak inne archiwa znajdujące się pod jurysdykcją niemiecką - reprezentuje władzę Trzeciej Rzeszy, oraz na fakt, iż w Poznaniu na czele instytucji tego samego rodzaju, takich jak np. Stadtbücherei czy Universitätsbibliothek, stoją dyrektorzy ${ }^{9}$. Jego prośba nie została najprawdopodobniej w ogóle rozpatrzona, gdyż po kilku dniach od dostarczenia tego dokumentu pozbawiono go funkcji kierownika poznańskiego ośrodka archiwalnego ${ }^{10}$. Niewykluczone, że wysłanie takiego właśnie pisma do namiestnika Rzeszy było jedną z przyczyn jego odwołania.

Jeśli chodzi o podporządkowanie państwowej służby archiwalnej w jednostkach terytorialnych, jakimi były okręgi Rzeszy, to w pierwszych tygodniach po likwidacji zarządu wojskowego na tych terenach kwestia ta nie została rozstrzygnięta. Archiwa w Poznaniu oraz w Gdańsku określano mianem archiwów państwowych (Staatsarchive), chociaż podlegały bezpośrednio Ministerstwu Spraw Wewnętrznych Rzeszy (RMdI), co świadczy o ich związku ze służbą archiwalną Rzeszy, a konkretnie z Generalnym Dyrektorem Pruskich Archiwów Państwowych i dyrektorem Archiwum Rzeszy w Poczdamie. Wkrótce dr Zipfel jako dyrektor Archiwum w Poczdamie wystosował do RMdI postulat dotyczący rozwiązania kwestii związanej z podporządkowaniem tych instytucji odpowiednim organom. Zaproponował, aby archiwa w Poznaniu oraz Gdańsku zmieniły nazwę na Archiwa Rzeszy, odpowiedni namiestnik Rzeszy miał objąć nadzór nad tymi instytucjami, a kierownictwo sprawowałby dyrektor Archiwum Rzeszy w Poczdamie, choć ministrowi spraw wewnętrznych pozostawiono możliwość wydawania werdyktów w niektórych sporach. Poza tym w piśmie umieszczono zapis o wydatkach

${ }^{7}$ M. Stażewski, Niemiecka polityka archiwalna na ziemiach polskich właczonych do Rzeszy 19391945, Warszawa-Łódź 1991, s. 73.

${ }^{8}$ Archiwum Państwowe miasta Poznania i województwa poznańskiego oraz jego archiwa terenowe. Przewodnik po zasobie archiwalnym, red. C. Skopowski, Warszawa 1969, s. 16.

${ }^{9}$ AP Poznań, RSH, sygn. 4946, s. 149-150.

${ }^{10}$ Tamże, s. 153. 
i wypłatach dla personelu. Pensje pracowników pomocniczych oraz koszty związane z podróżami pokrywałby urząd namiestnika Rzeszy, natomiast archiwiści i urzędnicy oddelegowani do pracy w tych archiwach $\mathrm{z}$ innych placówek mieli otrzymywać wynagrodzenie od władz, którym pierwotnie podlegalii" ${ }^{11}$.

Wiadomo, że zaproponowany przez dr. Zipfela projekt wszedł w życie, jednak z uwagi na braki źródłowe nie można ustalić, kiedy to dokładnie nastąpiło. Nie ulega wątpliwości, że obie instytucje zmieniły swoją nazwę na Reichsarchive. Jeśli chodzi o poznańskie archiwum to zmiana nazwy tej placówki musiała nastąpić pomiędzy grudniem 1939 r. a styczniem 1940 r., gdyż w piśmie z 5 grudnia 1939 r. ${ }^{12}$ używano jeszcze określenia Staatsarchive. Był to ostatni zachowany w źródłach dokument, w którym takie nazewnictwo występuje. Natomiast $w$ tym okresie prawdopodobnie nie używano jeszcze nazwy Archiwum Rzeszy. W styczniu 1940 r. funkcjonowało już tylko określenie Reichsarchiv. Znalazło się ono w piśmie skierowanym do ministra spraw wewnętrznych Rzeszy z 31 stycznia 1940 r. ${ }^{13}$ oraz sprawozdaniu dla dyrektora Archiwum Rzeszy w Poczdamie dotyczącym wszelkiego rodzaju działalności tej instytucji archiwalnej. W sprawozdaniu tym odniesiono się do dokumentu z 18 stycznia 1940 r., gdzie przy znaku pisma pojawił się symbol RA (Reichsarchiv), który świadczy o wprowadzeniu nowej nazwy funkcjonującej już z pewnością od kilku bądź kilkunastu dni ${ }^{14}$.

Poznańska placówka archiwalna po zmianie nazwy na Archiwum Rzeszy była jedynym archiwum państwowym znajdującym się na obszarze Okręgu Rzeszy Kraj Warty. W zaistniałej sytuacji kierownik tego archiwum podlegał namiestnikowi Rzeszy, co sprawiło, że służba archiwalna na tym terytorium była podporządkowana dwóm władzom (podobny model występował również w Okręgu Rzeszy Gdańsk Prusy-Zachodnie). W sprawach związanych z badaniami naukowymi bądź w kwestiach merytorycznych podlegała dyrektorowi Archiwum Rzeszy w Poczdamie, administracyjnie zaś Arthurowi Greiserowi jako namiestnikowi Rzeszy. Przy urzędzie namiestnika (Reichsstatthalterei) utworzono osobny referat archiwalny (Referat 16 - Archivwesen), którego siedziba znajdowała się w gmachu archiwalnym na Górze Przemysła, a którego szefem mianowano kierownika Archiwum Rzeszy w Poznaniu. Podpisywał on wszystkie dokumenty wystawiane przez referat I/16. W niektórych sytuacjach inny pracownik poznańskiego archiwum w zastępstwie kierownika składał swój podpis ${ }^{15}$.

\footnotetext{
${ }^{11}$ M. Stażewski, Niemiecka polityka archiwalna..., s. 51-52.

${ }^{12}$ AP Poznań, RSH, sygn. 904, s. 44.

${ }^{13}$ Tamże, s. 89.

${ }^{14}$ AP Poznań, Archiwum Rzeszy, sygn. 210, s. 14.

${ }^{15}$ M. Stażewski, Niemiecka polityka archiwalna..., s. 54-55.
} 
Niestety, z powodu niedostatecznej ilości źródeł nie można szczegółowo ustalić związku pomiędzy Archiwum w Poznaniu a urzędem namiestnika Rzeszy. Wiadomo jednak, że zgodnie z zarządzeniem namiestnika Rzeszy z 6 maja 1942 r. zaczęto przy korespondencji z władzami oraz innymi publiczno-prawnymi urzędami do tytułu „Der Reichsstatthalter in Warthegau” dodawać określenie „Reichsarchiv Wartheland"16. Na podstawie tego rozporządzenia można wywnioskować, iż poznańskie Archiwum było podporządkowane w kwestiach organizacyjnych namiestnikowi Rzeszy. Jeżeli chodzi o sprawy personalne pracowników, to sytuacja wygląda bardzo podobnie, gdyż były one załatwiane $\mathrm{w}$ urzędzie namiestnika, co ma swoje odzwierciedlenie $\mathrm{w}$ zachowanych źródłach ${ }^{17}$. Najprawdopodobniej również częściowe opłacanie działalności Archiwum leżało w gestii władz lokalnych.

Po zakończeniu działań wojennych na terenach włączonych do Rzeszy niemiecka służba archiwalna najpierw zajęła się przejęciem kontroli nad państwowym zasobem archiwalnym, a dopiero później podjęła próbę zorganizowania systemu opieki archiwalnej (Archiopflege) dla niepaństwowego zasobu archiwalnego, w skład którego wchodziły archiwa: miejskie, gminne, prywatne, gospodarcze, cechów oraz stowarzyszeń. System ten polegał na utworzeniu tzw. poradni archiwalnych (Archivberatungsstelle) oraz przydzieleniu do konkretnego obszaru opiekunów archiwalnych (Archiopfleger). Funkcję opiekunów piastowali zazwyczaj inspektorzy szkolni, nauczyciele oraz urzędnicy posiadający wyższe wykształcenie, którzy musieli wcześniej ukończyć kurs prowadzony przez profesjonalnych archiwistów. Model ten został zaczerpnięty z systemu wytworzonego w Prusach, który funkcjonował od 4 sierpnia 1937 r., kiedy weszło w życie rozporządzenie ministra spraw wewnętrznych Rzeszy ${ }^{18}$.

Kraj Warty jako jednostka administracyjna posiadał także swój system opieki archiwalnej, który został oparty na wzorcu pruskim z 1937 r. Jednak tutaj musiał on zostać stworzony od podstaw w przeciwieństwie do terenów włączonych do prowincji pruskich. Organizację tego modelu powierzono lokalnym władzom archiwalnym, które przy tworzeniu tych placówek zakładały, że będą one funkcjonować $w$ ramach władz samorządowych okręgu, czyli tzw. Gauselbstverwaltung ${ }^{19}$. Próby utworzenia systemu opieki archiwalnej w tym okręgu podjęto w połowie 1940 r., o czym świadczy sprawozdanie dr. Sandowa z 22 czerwca 1940 r., dotyczące Archiwum Rzeszy w Poznaniu. Autor wyjaśnia w nim, że z polecenia zwierzchnika władzy samorządowej

${ }^{16}$ AP Poznań, RSH, sygn. 756, s. 12.

17 Tamże, sygn. 1020, s. 441; sygn. 1025, s. 23.

18 A. Staszków, Archiwa prywatne w prowincji Górnego Śląska (1939-1945), „Archeion” 1981, t. 72, s. 79; D. Matelski, Grabież i restytucja polskich dóbr kultury..., s. 341.

${ }^{19}$ M. Stażewski, Niemiecka polityka archiwalna..., s. 65-66. 
okręgu (Gauhauptmann) rozpoczął organizowanie opieki archiwalnej oraz poradni archiwalnej. Przygotowując ten projekt, opierał się na modelu śląskim, do którego wprowadził kilka zmian dostosowanych do lokalnych warunków. Niestety, nie podał, o jakie różnice chodziło, lecz wspomniał, że w niedalekiej przyszłości poinformuje o szczegółach swojego planu ${ }^{20}$. Na postawie jego spostrzeżeń można zaryzykować stwierdzenie, iż poradnia archiwalna znajdowała się na terenie miasta Poznania, a osobą odpowiedzialną za jej prowadzenie był kierownik Reichsarchiv.

Według Kazimierza Kaczmarczyka, to właśnie Archiwum Rzeszy zajmowało się prowadzeniem poradni archiwalnej, o czym badacz wspomina w jednej ze swoich prac. Pisał w niej, że na czele poradni stał kierownik tego archiwum dr Weise, któremu pomagali pastor Sterlak oraz panna Bojenka. Jednak placówkę powołano dopiero w 1942 r., co nie uchroniło kościelnych, miejskich i prywatnych archiwaliów od zniszczenia i grabieży ${ }^{21}$.

Na dodatek wiadomo, że w poszczególnych rejencjach Okręgu Rzeszy Kraj Warty prowadzili swoją działalność opiekunowie archiwalni. Można to wywnioskować na podstawie zachowanej listy powiatowych "Archivpflegerów", zawierającej nazwiska, adresy i wykonywany przez nich zawód. Według istniejącego wykazu, w rejencji poznańskiej na osiemnaście regionów przypadało trzydziestu opiekunów, w rejencji inowrocławskiej w piętnastu okręgach było trzydziestu czterech opiekunów, a w rejencji łódzkiej utworzono jedenaście regionów, na które przypadało dwudziestu opiekunów ${ }^{22}$.

\section{Działalność}

Reprezentanci niemieckiej służby archiwalnej na terenach Kraju Warty już od samego początku swojej działalności podjęli próby odzyskania akt ewakuowanych przez poznańskie władze archiwalne. Efektem tych działań było sprowadzenie szesnastu skrzyń z najstarszymi i najcenniejszymi dokumentami, które zostały przejęte w połowie września 1939 r. przez wojsko niemieckie i odesłane do Berlina. Stamtąd trafiły do poznańskiego archiwum w kwietniu $1940 \mathrm{r} .{ }^{23}$ Poza tym udało się również odzyskać ewakuowane do Lubartowa akta kościelne z Gniezna i Poznania, które zostały najpierw zare-

${ }^{20}$ AP Poznań, Archiwum Rzeszy, sygn. 210, s. 15.

${ }^{21}$ K. Kaczmarczyk, Archiwum Państwowe..., s. 90.

${ }^{22}$ AP Poznań, RSH, sygn. 1075, s. 1-5.

${ }^{23}$ K. Kaczmarczyk, Archiwum Państwowe..., s. 85; A. Stebelski, Losy archiwów polskich w latach wojny 1939-1945, „Rocznik Warszawski” 1963, t. 4, s. 176. 
kwirowane przez Główny Urząd Bezpieczeństwa Rzeszy, a następnie przekazane do Archiwum Rzeszy w Poznaniu ${ }^{24}$.

Poza wyżej wymienionymi dokumentami służba archiwalna interesowała się wywiezionymi archiwami prywatnymi. W związku z tym poznańskie Archiwum podjęło próbę odnalezienia ewakuowanego przed wybuchem II wojny światowej zbioru hrabiego Skórzewskiego z Czerniejewa. W zaistniałej sytuacji zwrócono się do Urzędu Archiwalnego w Lublinie, który oznajmil, że akta te (według ich danych) uległy zniszczeniu w wyniku bombardowania w okolicach Dęblina ${ }^{25}$.

Dokumentem odnoszącym się do zabezpieczenia polskich archiwaliów przez niemieckie władze okupacyjne było rozporządzenie ministra spraw wewnętrznych Rzeszy wydane 13 listopada 1939 r. Zawarte w nim postulaty dotyczyły ustalenia zakresu działalności dla ewakuowanych, z ziem włączonych do Rzeszy, akt polskich władz i urzędów. W każdym z okręgów Rzeszy i we wszystkich prowincjach Prus, w których znalazły się ziemie państwa polskiego, ustanowiono po jednej placówce odpowiedzialnej za sprowadzenie rozproszonej dokumentacji wszystkich instytucji z obszaru jego działania. Jednostki ta miały nosić nazwę Centrala dla Sprowadzenia Wywiezionej Dokumentacji Urzędowej ${ }^{26}$.

W okręgu Poznań (od 29 stycznia 1940 r. zmienionego na Kraj Warty) realizację postanowień zawartych $\mathrm{w}$ rozporządzeniu ministra spraw wewnętrznych Rzeszy zlecono namiestnikowi, a konkretnie jego urzędowi. Ten w pierwszej kolejności, 23 listopada 1939 r., wystosował pismo do podległych mu placówek, w którym powołał się na tekst rozporządzenia RMdI. Ponadto wyznaczył prezydenta rejencji poznańskiej jako osobę odpowiedzialną za wydanie decyzji w sprawie utworzenia Centrali ${ }^{27}$. W dalszej kolejności, na podstawie pisma z 29 listopada 1939 r., podał do informacji prezydentów rejencji w Ciechanowie i Katowicach, że Centrala dla poznańskiego okręgu została utworzona przy prezydencie rejencji w Poznaniu ${ }^{28}$. Nowo powstała instytucja miała nawiązać współpracę z Archiwum Rzeszy w Poznaniu $\mathrm{w}$ celu zabezpieczenia dokumentacji niepotrzebnej do bieżącego użytku ${ }^{29}$. Zgodnie z raportem sporządzonym 7 marca 1940 r. przez Zentralstelle można stwierdzić, że zaangażowanie służby archiwalnej wpłynęło na organizację poznańskiej Centrali. Autor wspomina w nim o jakimś rozporządzeniu namiestnika Rzeszy w Poznaniu z 8 lutego 1940 r., które nie zachowało się do

\footnotetext{
${ }^{24}$ M. Stażewski, Niemiecka polityka archiwalna..., s. 90.

25 Tamże.

${ }^{26}$ AP Poznań, RSH, sygn. 904, s. 29-31.

27 Tamże, s. 35-36.

28 Tamże, s. 42.

${ }^{29}$ Tamże, s. 89.
} 
dziś, a które rozesłano do podporządkowanych mu władz ${ }^{30}$. Według Marka Stażewskiego, zarządzenie to zawierało informacje systematyzujące kwestie organizacyjne poznańskiej Centrali zgodnie z projektem wydanym wcześniej przez Archiwum Rzeszy ${ }^{31}$. Bardzo możliwe, że kierownikiem Zentralstelle był nadradca stanu dr Blume, ponieważ to właśnie jego nazwisko widnieje w raportach z działalności poznańskiej Centrali z lat 1939-194032.

Archiwum Rzeszy w Poznaniu stanęło przed ważnym zadaniem związanym z aktami instytucji i urzędów, które zakończyły swoją działalność. Większość $\mathrm{z}$ nich znajdowała się $\mathrm{w}$ posiadaniu administracyjnych władz okupacyjnych, dlatego poznańska placówka archiwalna musiała zapewnić im ochronę przed niewłaściwym działaniem ze strony jej powierników. Poza wprowadzonymi przez władze okupacyjne zarządzeniami w sprawie postępowania z przejętymi i zabezpieczonymi urzędowymi dokumentami (m.in. rozporządzenie z 13 listopada 1939 r.) podjęto próby ratowania zagrożonych materiałów archiwalnych, które na skutek złego traktowania mogły ulec zniszczeniu. Jednym z tego typu działań było wprowadzenie zakazu oddawania na makulaturę oraz niszczenia archiwaliów, co często bez zgody służby archiwalnej praktykowały niemieckie urzędy ${ }^{33}$.

Do kompetencji poznańskiej placówki archiwalnej należało przejmowanie archiwaliów z registratur byłych polskich urzędów, organizacji i instytucji. Pomimo zachowanych $\mathrm{w}$ niewielkim stopniu materiałów źródłowych można stwierdzić, że na początku działalności niemieckiej służby archiwalnej na tych terenach w zasobie Archiwum Rzeszy znalazły się akta Komisji Kolonizacyjnej ${ }^{34}$ oraz dawnego Urzędu Wojewódzkiego ${ }^{35}$.

Oprócz wyżej wymienionej dokumentacji w skład zasobu zostały włączone najprawdopodobniej inne akta polskich urzędów i instytucji, przechowywane wcześniej w składnicach akt. Świadczyć o tym może okólnik wydany 28 lipca 1942 r. przez Referat I/16, działający przy urzędzie namiestnika w Poznaniu, zaadresowany do prezydentów rejencji w Poznaniu, Inowrocławiu i Łodzi oraz landratów, komisarzy obwodowych oraz nadburmistrzów pełniących swoje obowiązki na terenie Kraju Warty. Dokument ten zawierał wytyczne dotyczące materiałów archiwalnych o znaczeniu politycznym, wojskowych, a także starych rękopisów i dokumentów, które należało przesłać do Archiwum Rzeszy w Poznaniu ${ }^{36}$.

\footnotetext{
30 Tamże, s. 121-122.

31 M. Stażewski, Poszukiwanie ewakuowanych akt polskich..., s. 217.

32 AP Poznań, RSH, sygn. 904, s. 43, 141, 162, 173, 176.

33 Tamże, sygn. 1020, s. 318.

34 Tamże, s. 317.

35 Tamże, sygn. 904, s. 100.

36 Tamże, s. 193.
} 
Do okólnika z 28 lipca 1942 r. dołączono pismo, w którym ustalono podział na dwie kategorie akt, jakie następnie miały zostać niezwłocznie przewiezione do poznańskiego archiwum. Do pierwszej z nich przydzielono: materiały polskiego wywiadu i kontrwywiadu, akta natury wojskowej zawierające informację o niemieckości w Kraju Warty, a dotyczące wojskowego przeszkolenia, akta procesów politycznych oraz akta dotyczące kwestii żywienia, mostów, dróg wodnych i lądowych. Natomiast materiały archiwalne zakwalifikowane do drugiej grupy to: dokumenty pergaminowe, zabytkowe rękopisy, akta pochodzące sprzed 1806 r., akta instytucji centralnych takich jak: nadprezydium prowincji, rejencji, komisji generalnych, komisji kolonizacyjnych i akta kuratoriów szkolnych, urzędu wojewódzkiego, szkolnych władz nadzorczych oraz instytucji kościelnych z czasów polskiego zarządu ${ }^{37}$. Założono, że ekspertyzę archiwalną tego zasobu wykonają opiekunowie archiwalni, jednak w związku z brakiem informacji o efektach ich prac nie można ustalić, na jaką skalę dokonywała się akcja zabezpieczenia archiwaliów w Kraju Warty.

Po zajęciu Wielkopolski przez wojska niemieckie władze archiwalne przystąpiły do konfiskaty archiwaliów kościelnych. 4 października 1939 r., po dokonaniu rewizji i przesłuchaniu pracowników, opieczętowano główny magazyn Archiwum Archidiecezjalnego w Poznaniu, co rozpoczęło proces likwidacji placówki. Pod koniec 1939 r. losy tej instytucji były już praktycznie przesądzone, gdyż przybyli do Poznania Niemcy bałtyccy, którzy uzyskali poparcie Himmlera, wybrali budynek archiwum na miejsce przechowywania swoich zbiorów. Jeszcze dr Hermann Gollub podjął próby ratowania placówki, ale ostatecznie pod koniec września 1940 r. rozpoczęto wywożenie akt kościelnych z gmachu archiwalnego do pomieszczeń magazynowych Archiwum Rzeszy w Poznaniu oraz kościoła farnego, który został zamieniony na magazyn archiwalny ${ }^{38}$.

W ramach swojej działalności poznańskie Archiwum zabezpieczyło akta innych kościelnych instytucji archiwalnych. Na początku listopada $1939 \mathrm{r}$. podjęto decyzję o zamknięciu katedry we Włocławku, a wraz z nim tamtejszego archiwum. Archiwalia związane z kurią diecezjalną i z sądem kościelnym postanowiono przewieźć w czerwcu i lipcu 1942 r. do magazynów Archiwum Rzeszy w Poznaniu ${ }^{39}$. Podobna sytuacja miała miejsce z aktami Archiwum

37 Tamże, s. 194-197.

${ }^{38}$ J. Nowacki, Losy wojenne Archiwum Archidiecezjalnego w Poznaniu, "Sprawozdanie Poznańskiego Towarzystwa Przyjaciół Nauk" 1945/1946, t. 13, s. 45.

${ }^{39}$ S. Librowski, Sprawozdanie z działalności Archiwum Diecezjalnego we Wtoctawku 1945-1958, "Archiwa, Biblioteki i Muzea Kościelne" 1959, t. 1, z. 1, s. 145. 
Archidiecezjalnego w Gnieźnie, które po zamknięciu katedry w listopadzie 1939 r. zostały po paru miesiącach przetransportowane do Poznania ${ }^{40}$.

Za konfiskatą archiwów diecezjalnych, kapitularnych oraz związanych z parafiami na terytorium Kraju Warty stały władze policyjne, a niemiecka służba archiwalna musiała się temu podporządkować oraz udzielić pomocy przy rekwizycji materiałów archiwalnych. Na tej płaszczyźnie swoją działalność prowadził także dr Gollub, który angażował się w proces przejmowania archiwaliów z kościołów parafialnych, a co za tym idzie - zabezpieczał zagrożone dokumenty. W związku z tym, że duża liczba parafii pozostawała bez proboszczów, a dokumentacja znajdująca się w nich została pozbawiona opieki, przetransportowanie tych akt do poznańskiego Archiwum miało zapobiec ich zniszczeniu oraz dewastacji ${ }^{41}$.

Nie można dokładnie oszacować, jaka część materiałów archiwalnych i akt kościelnych została przejęta przez niemiecką służbę archiwalną z poszczególnych parafii i dekanatów. Na podstawie sprawozdania Adama Kaletki dla Wydziału Archiwów Państwowych można jedynie wywnioskować, że do zasobu Archiwum Rzeszy w Poznaniu przyłączono znaczną liczbę akt parafialnych i dekanalnych ${ }^{42}$. Wiele $z$ tych archiwaliów przechwyciła niemiecka policja, która wykorzystywała je do własnych celów, a następnie, dopiero po wnikliwej analizie, przekazywała je dalej do archiwów państwowych.

Ważną częścią archiwaliów kościelnych były księgi metrykalne, które już w początkowej fazie okupacji hitlerowskiej trafiły w ręce Tajnej Policji Państwowej (Gestapo). W akcję konfiskowania i gromadzenia ksiąg metrykalnych z terytorium Kraju Warty zaangażowano również poznańskie Archiwum, które z polecenia namiestnika Rzeszy przejmowało, ewidencjonowało, i sprawowało opiekę nad tymi księgami ${ }^{43}$. Na miejsce przechowywania wyznaczono kościół św. Michała w Poznaniu, gdzie stworzono odpowiednie warunki do magazynowania tego rodzaju akt. Zgromadzone księgi metrykalne znajdowały się tam zapewne do lipca 1940 r., kiedy Archiwum Rzeszy w Poznaniu przestało pełnić funkcję opiekuna ksiąg metrykalnych i przekazało je nowo powstałemu Urzędowi do Spraw Genealogicznych w Poznaniu (Gausippenamt Posen) ${ }^{44}$, którego zadaniem było gromadzenie ksiąg kościelnych służących do badań genealogicznych dla pozyskania dowodów na czystość rasy niemieckiej.

Państwowa służba archiwalna była zainteresowana zabezpieczeniem dokumentacji zgromadzonej w archiwach miast i gmin, dlatego często jej przed-

${ }^{40}$ K. Śmigiel, Losy archiwów, bibliotek i muzeów kościelnych pod rządami A. Greisera (19391945), "Archiwa, Biblioteki i Muzea Kościelne” 1976, t. 32, s. 276.

${ }^{41}$ AP Poznań, Akta własne, sygn. 633, s. 33-34v.

42 Tamże, s. 11.

${ }^{43}$ Tamże, Archiwum Rzeszy, sygn. 210, s. 13.

${ }^{44}$ M. Stażewski, Niemiecka polityka archiwalna..., s. 121. 
stawiciele namawiali władze miejskie do oddawania w depozyt najstarszych i najcenniejszych archiwaliów. Takie działanie argumentowano potrzebą odpowiedniego zabezpieczenia, opracowania i udostępniania tej dokumentacji. Wiele archiwów miejskich decydowało się na zdeponowanie swojego zasobu w archiwach o zasobie historycznym. Na terytorium Wielkopolski spora część archiwaliów miast została przekazana jako depozyt jeszcze w XIX w., a na początku II wojny światowej przechowywano je w Archiwum Rzeszy w Poznaniu. Dopiero pod koniec 1943 r. Archiwum Miejskie w Poznaniu włączyło do swojego zasobu akta staropolskie, pozostawiając nadal dziewiętnastowieczną dokumentację w budynku na Górze Przemysła ${ }^{45}$. Wiadomo, że Archiwum Miejskie w Poznaniu w okresie okupacji posiadało księgi urzędów stanu cywilnego od 1874 r. ${ }^{46}$

Ponadto niemiecka służba archiwalna od samego początku okupacji interesowała się zbiorami prywatnymi. Świadczy o tym m.in. relacja Mariana Swinarskiego, którego zatrudnił ówczesny kierownik Archiwum Rzeszy w Poznaniu dr Hermann Gollub w charakterze osoby zajmującej się zbieraniem zagrożonych oraz niezidentyfikowanych archiwaliów prywatnych i przewożeniem ich do poznańskiej palcówki archiwalnej ${ }^{47}$.

Przejmowane archiwalia bardzo często trafiały do Archiwum Rzeszy $\mathrm{w}$ Poznaniu $\mathrm{w}$ formie depozytu, podobnie jak to miało miejsce $\mathrm{z}$ aktami miejskimi. Wyżej wymieniony dr Gollub przyczynił się do uratowania wielu prywatnych bibliotek i zbiorów, w tym biblioteki Zygmunta Wojciechowskiego, którą przejął i przekazał do poznańskiego archiwum jako Depositum Wojciechowski ${ }^{48}$. Poza samą biblioteką, która zawierała oprócz książek również czasopisma i broszury, przekazano mu spis liczący 2595 pozycji ${ }^{4}$.

Niemieccy archiwiści liczyli, że uda im się zebrać jak największą liczbę najcenniejszej dokumentacji z polskich archiwów prywatnych, którą później wykorzystają do własnych celów. Już po kilku miesiącach swojej aktywności w tej dziedzinie okazało się to niemożliwe, gdyż w większości przypadków zasób ten był ewakuowany albo uległ zniszczeniu. Za całkowicie zdewastowane archiwum znajdujące się na terenie Wielkopolski należy uznać archiwum Radziwiłłów w Antoninie. Natomiast częściowemu zniszczeniu uległy archiwa Raczyńskich z Rogalina oraz hrabiego Mycielskiego z podpoznańskiej miejscowości Kobyle Pole.

${ }^{45}$ M.J. Mika, Dzieje Archiwum Miejskiego w Poznaniu, Warszawa 1975, s. 33.

${ }^{46}$ AP Poznań, Akta miasta Poznania, sygn. 16244, s. 59.

${ }^{47}$ Tamże, Akta własne, sygn. 633, s. 33-34v.

${ }^{48}$ L. Adamczewski, P. Piątkiewicz, Podziemny skarbiec Rzeszy. Tajemnice fortyfikacji międzyrzeckich, Zakrzewo 2009, s. 19.

${ }^{49}$ M. Wojciechowski, Wojenne losy biblioteki Zygmunta Wojciechowskiego, [w:] W kręgu polityki, dyplomacji i historii XX wieku, red. B. Rakowski, A. Skrzypek, Łódź 2000, s. 270. 
Wszystkie odnalezione szczątki archiwów prywatnych zostały zarekwirowane i przeniesione do Reichsarchiv Posen. Instytucja ta zabiegała o archiwalia polskich rodzin magnackich będących częścią zbioru biblioteki Poznańskiego Towarzystwa Przyjaciół Nauk. Za pośrednictwem miejscowego Gestapo starania przyniosły oczekiwany efekt, w lipcu 1940 r. bowiem przekazano je poznańskiej placówce archiwalnej ${ }^{50}$. Dodatkowo, jak wynika z raportu Adama Kaletki, do Archiwum Rzeszy w Poznaniu trafiły archiwalia rodzin takich jak: Szczanieccy, Chłapowscy czy Skórzewscy ${ }^{51}$.

W zakresie działalności archiwów mieści się opracowanie materiałów archiwalnych, które należy wykonać, aby w następnej kolejności można było udostępniać je dla celów naukowych w postaci uporządkowanych akt. Pojęcie opracowanie w czasie okupacji nabiera nieco innego znaczenia niż we współczesnej archiwistyce. Obejmuje swoim zakresem szereg czynności, które niemiecka służba archiwalna miała wykonywać w celu przechowywania $\mathrm{w}$ magazynach archiwalnych, a następnie udostępniania $\mathrm{w}$ formie umożliwiającej sprawne korzystanie $\mathrm{z}$ zabezpieczonego zasobu. W skład prac podejmowanych $w$ ramach opracowania materiałów archiwalnych wchodzą takie działania jak: segregacja i selekcja akt, spisywanie dokumentów, wydzielanie i brakowanie dokumentacji, nadawanie układu określonym zespołom archiwalnym oraz przygotowywanie dla nich pomocy ewidencyjnych i informacyjnych. Do wymienionych czynności należałoby dodać rozlokowanie materiałów archiwalnych w magazynach według określonego porządku. W normalnych warunkach prace, takie jak: spisywanie, brakowanie, segregowanie, należą do zadań placówek wytwarzających poszczególną dokumentację, a nie służby archiwalnej ${ }^{52}$.

W Archiwum Rzeszy w Poznaniu wykonywanie jakichkolwiek prac wewnętrznych było początkowo bardzo utrudnione. Wynikało to z braku inwentarzy archiwalnych, które na początku września 1939 r. zostały ewakuowane w głąb kraju. Z uwagi na problemy dotyczące korzystania $\mathrm{z}$ zasobu archiwalnego postanowiono przygotować spis zgromadzonej w magazynach dokumentacji wraz z rozmieszczeniem jej na półkach. Działania te przyniosły spodziewany efekt, gdyż umożliwiły sprawne korzystanie ze zgromadzonego zasobu. Prace te były wykonywane w bardzo trudnych warunkach, ponieważ z powodu siarczystego mrozu większość pomieszczeń znajdujących się na Górze Przemysła była niedogrzana ${ }^{53}$.

Największy problem przy opracowaniu zasobu, z jakim spotkała się niemiecka służba archiwalna, dotyczył dokumentacji, która w wyniku wojny

\footnotetext{
${ }^{50}$ M. Stażewski, Niemiecka polityka archiwalna..., s. 132-133.

${ }^{51}$ AP, Poznań, Akta własne, sygn. 633, s. 11.

${ }_{52}$ M. Stażewski, Niemiecka polityka archiwalna..., s. 169.

53 AP Poznań, Archiwum Rzeszy, sygn. 210, s. 8-9.
} 
uległa przyspieszonemu procesowi archiwizacji. Akta tego rodzaju cieszyły się największym zainteresowaniem niemieckich urzędów i instytucji naukowych w związku z prowadzeniem przez te placówki badań, dlatego takie materiały opracowywano zazwyczaj w pierwszej kolejności.

Wobec dużej ilości dokumentacji, która w ciągu krótkiego czasu trafiła do poznańskiej placówki archiwalnej, do porządkowania wybierano zespoły najbardziej przydatne okupacyjnym władzom. Nie zachowały się akta świadczące o tym, które zespoły w pierwszej kolejności zostały poddane procesowi opracowania. Jednak wiadomo, że pierwotnie nie podjęto się opracowania akt Urzędu Wojewódzkiego, pomimo że cieszyły się dużą popularnością wśród użytkowników. Dopiero po interwencji namiestnika Rzeszy Arthura Greisera zdecydowano się zapewne na rozpoczęcie prac obejmujących porządkowanie tych akt, pomimo problemu z miejscem, w którym można byłoby je przeprowadzić ${ }^{54}$.

Przy opracowaniu zespołów archiwalnych o dużej objętości, takich jak zespół Urzędu Wojewódzkiego w Poznaniu, prace wykonywano w kilku etapach. Na początku przeprowadzano selekcję i brakowanie, które odbywały się na poziomie instytucji wytwarzających dane akta. Takie rozwiązanie wybrano zapewne ze względu na trudną sytuację lokalową $\mathrm{w}$ archiwach oraz koszty, jakie wiązały się z transportem materiałów archiwalnych. Następnie, po wyselekcjonowaniu wartościowych akt, przewożono je do odpowiedniego archiwum historycznego, gdzie rejestrowano je i nadawano im odpowiedni układ. Na tym etapie odbywała się również właściwa selekcja, po czym przygotowywano repertoria i umieszczano archiwalia w magazynach.

W kolejnych latach przejmowano znacznie mniejszą ilość dokumentacji, co w konsekwencji wpłynęło na bardziej dokładne opracowanie zasobu. Rozpoczęto opracowywać zespoły, które dotychczas pomijano lub przejmowano na bieżąco $\mathrm{z}$ poszczególnych instytucji. Warunki pracy $\mathrm{w}$ archiwach praktycznie nie uległy zmianie $\mathrm{w}$ porównaniu z pierwszym okresem okupacji. Niemiecka służba archiwalna $\mathrm{w}$ tym czasie podejmowała prace $\mathrm{w}$ zakresie opracowania zespołów archiwalnych w pierwszej kolejności dla instytucji państwowych, a następnie dla indywidualnych petentów prowadzących badania naukowe ${ }^{55}$.

Prace wykonywane przez personel Archiwum Rzeszy w Poznaniu nie były zawsze starannie realizowane. Niefachowy personel często pracował w mało efektywny sposób, a wartość jego opracowań była mierna. Przyczyny takiego stanu rzeczy należy upatrywać w braku kontroli nad osobami zatrudnionymi przez kierownictwo Archiwum oraz w złej organizacji pracy. Na dodatek świeżo przyjęci pracownicy nie otrzymywali od swoich prze-

\footnotetext{
${ }^{54}$ Tamże, RSH, sygn. 904, s. 100.

${ }^{55}$ M. Stażewski, Niemiecka polityka archiwalna..., s. 174-175.
} 
łożonych żadnych wytycznych dotyczących wykonywanych obowiązków. Najlepszym przykładem złego zarządzania był fakt, iż każdy kierownik tej placówki wprowadził inny system sygnowania nowo przejętej dokumentacji, co znacznie utrudniło korzystanie $\mathrm{z}$ akt i przeprowadzanie kwerend archiwalnych ${ }^{56}$.

W kwestii selekcji i brakowania dokumentacji polegano głównie na umiejętnościach archiwistów niemieckich. Z powodu braku jednolitych kryteriów postępowania $\mathrm{z}$ tego typu dokumentacją do procesu brakowania wyznaczano te materiały, które niemiecka służba archiwalna uważała za bezużyteczne. Najczęściej przed zniszczeniem chroniono archiwalia mającą praktyczne znaczenia dla władz niemieckich, które posługiwały się nią głównie do celów politycznych, policyjnych, propagandowych i gospodarczych. Do tej grupy trzeba zakwalifikować również akta o dużym znaczeniu historycznym, szczególnie te, które powstały na skutek działalności niemieckich instytucji lub osób pochodzenia niemieckiego, a mające związek z niemieckimi sprawami.

Archiwiści niemieccy działający na terenie Poznania, według relacji Kazimierza Kaczmarczyka, dopuszczali się masowego brakowania akt, nie stosując się przy tym do zasad archiwistyki, na co wpływ miał z pewnością brak kontroli ${ }^{57}$. Zdarzały się sytuacje, w których materiały archiwalne o dużej wartości zostały poddane przez pomyłkę brakowaniu. Jako przykład można podać akta zarządu dóbr Thurn-Taxis z XIX w., które przez lekkomyślność archiwistów trafily do fabryki papieru ${ }^{58}$.

Prowadzone przez niemiecką służbę archiwalną czynności selekcji i brakowania miały negatywne skutki dla polskich akt, a co za tym idzie - także polskiej nauki. W okresie okupacji doszło do utraty znacznej części cennych materiałów archiwalnych, chociaż trudno dzisiaj ustalić dokładnie, jaka liczba akt została zniszczona $\mathrm{w}$ wyniku błędnie przeprowadzonego procesu brakowania ${ }^{59}$.

Ostatni z etapów opracowania, czyli sporządzanie pomocy archiwalnych, ograniczyło się do wykonywania spisów i inwentarzy kartkowych uporządkowanych zespołów. Wynikało to z warunków, jakie panowały w okresie okupacji hitlerowskiej, oraz z braku czasu, który należałoby poświęcić, aby wykonać pomoce archiwalne wyższego rzędu. W związku z tym większość sporządzonych wtedy pomocy archiwalnych miała charakter przejściowy, ponieważ zakładano w późniejszym okresie ich weryfikację i powtórne opracowanie.

\footnotetext{
${ }^{56}$ AP Poznań, Akta własne, sygn. 633, s. 9v-10.

${ }^{57}$ K. Kaczmarczyk, Archiwum Państwowe..., s. 88-89.

${ }^{58}$ Tamże, s. 92.

${ }^{59}$ M. Stażewski, Niemiecka polityka archiwalna..., s. 181.
} 
Obok gromadzenia i opracowania archiwaliów bardzo ważną funkcją archiwów, wynikającą z dwóch poprzednich, jest udostępnianie. W okresie II wojny światowej w każdej placówce archiwalnej kwestia udostępniania wyglądała nieco inaczej. Wynikało to przede wszystkim z: liczby opracowanych jednostek, zasięgu terytorialnego działalności placówek archiwalnych oraz spraw lokalowych, osobowych i technicznych.

Zasady udostępniania materiałów archiwalnych w poszczególnych archiwach były określone oddzielnymi przepisami (regulaminem i taryfą opłat) dla każdej państwowej instytucji archiwalnej w danym okręgu. Udostępnianie akt miało miejsce także $w$ Reichsarchiv, gdzie w pierwszej kolejności prawo do korzystania z zasobu miały instytucje władz państwowych, a głównymi użytkownikami były osoby pochodzenia niemieckiego oraz obcokrajowcy, którzy musieli otrzymać pozwolenie na korzystanie z archiwaliów drogą dyplomatyczną. Udostępnianie materiałów archiwalnych dla celów naukowych i urzędowych było z reguły bezpłatne, lecz za użytkowanie akt $\mathrm{w}$ interesie prywatnym należało zapłacić zgodnie z taryfikatorem opła $t^{60}$.

Dla Archiwum Rzeszy w Poznaniu zachował się regulamin korzystania z zasobu archiwalnego. Jest to jeden z nielicznych dokumentów, który ilustruje przepisy, jakie obowiązywały użytkowników w niemieckich archiwach na okupowanych ziemiach polskich. Usystematyzował on takie kwestie jak: uzyskanie pozwolenia na użytkowanie akt, zasady korzystania $\mathrm{z}$ archiwaliów, proces wypożyczenia akt innym niemieckim placówkom. W regulaminie zamieszczono harmonogram otwarcia czytelni, która $\mathrm{w}$ dni robocze była czynna od godziny 8.00 do 17.00, a w sobotę do godziny 13.00. Użytkownicy mieli obowiązek stosować się do poleceń wydawanych przez dyżurującego urzędnika. Należało dbać o akta oraz nie wolno było nanosić żadnych adnotacji i zapisków na wypożyczoną dokumentację. Jeśli osoba korzystająca z akt naruszała wydane przepisy dotyczące postępowania $\mathrm{z}$ archiwaliami, mogła zostać przez dyżurującego pozbawiona możliwości użytkowania dokumentów, jednocześnie przeciwko takiemu użytkownikowi wszczynano postępowanie karne. Przy Archiwum Rzeszy w Poznaniu funkcjonowała biblioteka, z której poza pracownikami mogli korzystać petenci, ale tylko pod warunkiem wydania zgody przez dyżurującego, natomiast wypożyczanie książek na zewnątrz było zakazane. Powołując się na ustawę o obywatelstwie Rzeszy, regulamin wykluczał z grona korzystających ludność pochodzenia żydowskiego. Warto dodać, że według instrukcji użytkowania nie wolno było m.in.: jeść posiłków w pracowni naukowej, wynosić archiwaliów, repertoriów i książek poza czytelnię, przeszkadzać innym użytkownikom. Za tego typu naruszenia

\footnotetext{
${ }^{60}$ Tamże, s. 182.
} 
użytkownik mógł zostać pozbawiony praw do korzystania z materiałów archiwalnych ${ }^{61}$.

Dla poznańskiej instytucji archiwalnej nie zachowały się żadne dane statystyczne przedstawiające liczbę osób korzystających z udostępnianego zasobu. Wiadomo jedynie, że największy procent prowadzonych kwerend prywatnych dotyczył genealogii, a konkretnie poszukiwania informacji poświadczających przynależność danej osoby do rasy aryjskiej. Według Kazimierza Kaczmarczyka, liczba użytkowników pochodzenia niemieckiego, którzy szukali dowodów potwierdzających swoją niemieckość, znacznie zmalała w stosunku do badaczy prowadzących poszukiwania przed wojną ${ }^{62}$.

W 1943 r. ograniczono udostępnianie zasobu archiwalnego we wszystkich archiwach na ziemiach polskich włączonych do Rzeszy. Było to spowodowane prowadzeniem tzw. wojny totalnej, co skutkowało utrudnieniami polegającymi na zmniejszeniu zakresu działań związanych z udostępnianiem materiałów archiwalnych. W zaistniałej sytuacji Archiwum Rzeszy w Poznaniu postanowiło 18 stycznia 1943 r. zamknąć pracownię naukową dla osób korzystających z niej osobiście, a kwerendy wykonywano tylko i wyłącznie poprzez wysłanie pisemnego wniosku, jeżeli te nie wymagały bardziej dokładnych poszukiwań. Ponadto sporządzono listę spraw, które w pierwszej kolejności powinny być załatwiane poprzez udostępnianie odpowiedniej dokumentacji. Podzielono je na trzy grupy: sprawy decydujące dla prowadzenia wojny (wyżywienie i rolnictwo, kwestie leśnictwa, udział w pracy i postawa podczas wykonywanej pracy), ważne dla prowadzenia wojny (obywatelstwo, historia niemieckości w Kraju Warty, prześladowania polskiego ruchu oporu i Niemców na obczyźnie, herby i nazwy miejscowości) oraz te związane z prowadzeniem działań wojennych (struktura administracyjna, wymiana archiwalna z Generalnym Gubernatorstwem, zmiana nazwisk osób oraz sprawy finansowe $)^{63}$.

Wraz z coraz bardziej skomplikowaną sytuacją na froncie wschodnim wprowadzano większe ograniczenia dostępu do archiwaliów. Najpierw na podstawie zarządzenia z 27 lipca 1944 r. zaostrzono przepisy odnoszące się do załatwiania kwerend. Bezzwłocznie przeprowadzano tylko te, które były bardzo pilne, a pozostałe odłożono w czasie, aż do momentu ustabilizowania się sytuacji na froncie. Kolejne rozporządzenie Generalnego Dyrektora Pruskich Archiwów Państwowych z 11 września 1944 r. dotyczyło całkowitego zakazu udostępniania materiałów archiwalnych dla celów prywatnych. Opierając się na tym zarządzeniu, można wywnioskować, że władze w ostatnim okresie wojny dążyły do zamknięcia archiwów oraz redukcji personelu

\footnotetext{
${ }^{61}$ AP Poznań, Archiwum Rzeszy, sygn. 210, s. 39-47.

${ }^{62}$ K. Kaczmarczyk, Archiwum Państwowe..., s. 93.

${ }^{63}$ AP Poznań, RSH, sygn. 182, s. 16-18.
} 
archiwalnego. Same archiwa starały się hamować poczynania przełożonych w takim stopniu, w jakim było to możliwe ${ }^{64}$.

Przedstawiając proces udostępniania archiwaliów w okresie okupacji hitlerowskiej, warto zastanowić się nad tym, kto najczęściej sięgał po dokumentację archiwalną oraz w jakim celu była ona wykorzystywana.

Jeżeli chodzi o „użytkowników instytucjonalnych”, w pierwszej kolejności należy wymienić różnego rodzaju władze policyjne, którym obowiązkowo udostępniano materiały archiwalne zawierające cenne informacje. W materiałach źródłowych zachowały się akta potwierdzające współpracę Archiwum Rzeszy w Poznaniu ze Służbą Bezpieczeństwa Reichsführera SS (Sicherheitsdienst des Reichsführer SS-SD), które dotyczyły informowania władz policyjnych o znalezionych dokumentach o charakterze politycznym, w zamian za co oczekiwano, iż SD będzie zwracało się o poradę $\mathrm{w}$ kwestiach archiwalnych ${ }^{65}$. Z uwagi na brak dokładniejszych danych na ten temat, nie można zobrazować, jak wyglądała dalsza współpraca.

Poza placówkami policyjnymi z poznańskiego Archiwum korzystały instytucje wojskowe. Wojskowa służba archiwalna przybyła do Poznaniu już $\mathrm{w}$ pierwszych dniach po zakończeniu działań wojennych prowadzonych w Wielkopolsce. Często w późniejszym okresie dostarczano placówkom wojskowym dane, które znajdowały się w aktach, a zdarzały się przypadki wypożyczania tej dokumentacji na zewnątrz. Część akt, dotyczących m.in. powstań wielopolskiego i śląskiego, została przejęta przez Archiwum Wojskowe w Oliwie.

Niejednokrotnie władze administracyjne wykorzystywały archiwalia przechowywane w magazynach Archiwum Rzeszy w Poznaniu. Obiektem zainteresowania tych instytucji były głównie akta gospodarcze, prawne, administracyjne i dokumentacja osobowa.

Udostępnianie materiałów archiwalnych osobom prywatnym polegało głównie na wyszukiwaniu $\mathrm{w}$ zasobie informacji o charakterze genealogicznym, a następnie wydawaniu zaświadczeń i odpisów dokumentacji, którą uważano za przydatną w celach osobistych. Jak już wcześniej wspomniałem, liczba prowadzonych badań naukowych znacznie zmalała w okresie okupacji. Było to związane z całkowitym ograniczeniem dostępu do zasobu dla obywateli polskich oraz z warunkami, jakie panowały podczas okupacji. Nie należy jednak pominąć grupy naukowców niemieckich, którzy korzystali z archiwaliów. Przypuszczalnie byli to lokalni badacze zajmujący się historią regionalną ${ }^{66}$.

\footnotetext{
${ }^{64}$ M. Stażewski, Niemiecka polityka archiwalna..., s. 185.

${ }^{65}$ AP Poznań, Archiwum Rzeszy, sygn. 210, s. 10.

${ }^{66}$ M. Stażewski, Niemiecka polityka archiwalna..., s. 188-189.
} 
Ostatnią grupą korzystającą z materiałów archiwalnych byli pracownicy Reichsarchiv Posen, którzy wykonywali kwerendy w celach zawodowych. Prowadzili oni głównie badania w zakresie tzw. programu wschodniego (Ostprogramm). Opracowaniem tematu, jaki w ramach tego projektu zlecono Archiwum, dotyczącym burmistrzów, rajców i ławników na terenach wschodnich poza granicą dawnej Rzeszy do około 1400 r., zajął się zapewne jeden $\mathrm{z}$ dwóch pracujących tam wtedy niemieckich archiwistów. Nie wiadomo, jak wyglądał dokładny przebieg prac. Jedyną informacją jest to, że w spisie wszystkich tematów dotyczących programu wschodniego z marca 1941 r. został umieszczony ten właśnie, przeznaczony dla Archiwum Rzeszy w Poznaniu. Może świadczyć to o tym, że był on opracowany. Nie ma również informacji, który z zatrudnionych wtedy archiwistów, dr Gollub czy dr Böhm, podjął się tego zadania. W sprawozdaniu z 24 maja $1940 \mathrm{r}$. dr Böhm nie wspominał o badaniach związanych z tym tematem, napisał natomiast, że przygotował wstępne materiały do pracy o "Osadnictwie wiejskim w Wielkopolsce na podstawie prawa niemieckiego" ${ }^{67}$. Dr Gollub także interesował się osadnictwem niemieckim w Wielkopolsce, a w szczególności tym zlokalizowanym na pograniczu Śląska ${ }^{68}$.

\section{Podsumowanie}

Wybuch II wojny światowej miał znaczący wpływ na dalsze dzieje Archiwum Państwowego w Poznaniu. Od tej pory przez następnych kilka lat znalazło się ono pod niemieckim zarządem archiwalnym, co oznaczało zmianę organizacji tej instytucji. Wprowadzono niemieckie prawo archiwalne, które obowiązywało na całym obszarze włączonym do Rzeszy, zmieniono nazwę Archiwum na Reichsarchiv Posen, nadzór nad zasobem powierzono niemieckim urzędnikom archiwalnym oraz wdrożono nowy system opieki archiwalnej. Wszystkie te działania doprowadziły do przekształcenia polskiej placówki historycznej w niemiecki urząd archiwalny.

\section{Bibliografia}

Materiały archiwalne

Archiwum Państwowe w Poznaniu

Akta miasta Poznania, sygn. 16244.

Akta własne, sygn. 633.

${ }^{67}$ AP Poznań, RSH, sygn. 1020, s. 322.

${ }^{68}$ Tamże, Akta własne, sygn. 633, s. 10. 
Archiwum Rzeszy w Poznaniu, sygn. 210.

Namiestnik Rzeszy w Okręgu Kraju Warty - Poznań, sygn. 182, 756, 904, 1020, 1025, 1075, 4946.

\section{Opracowania}

Adamczewski L., Piątkiewicz P., Podziemny skarbiec Rzeszy. Tajemnice fortyfikacji międzyrzeckich, Zakrzewo 2009.

Archiwum Państwowe miasta Poznania i województwa poznańskiego oraz jego archiwa terenowe. Przewodnik po zasobie archiwalnym, red. C. Skopowski, Warszawa 1969.

Kaczmarczyk K., Archiwum Państwowe w Poznaniu w czasie okupacji niemieckiej, „Archeion” 1948, t. 17.

Kaczmarczyk K., Adam Henryk Kaletka (1887-1956), „Archeion” 1956, t. 26.

Librowski S., Sprawozdanie z działalności Archiwum Diecezjalnego we Wtoctawku 1945-1958, „Archiwa, Biblioteki i Muzea Kościelne" 1959, t. 1, z. 1.

Matelski D., Grabież i restytucja polskich dóbr kultury: od czasów nowożytnych do czasów wspótczesnych, t. 1, Kraków 2006.

Mika M.J., Dzieje Archiwum Miejskiego w Poznaniu, Warszawa 1975.

Nowacki J., Losy wojenne Archiwum Archidiecezjalnego w Poznaniu, „Sprawozdanie Poznańskiego Towarzystwa Przyjaciół Nauk" 1945/1946, t. 13.

Staszków A., Archiwa prywatne w prowincji Górnego Ślaska (1939-1945), „Archeion” 1981, t. 72.

Stażewski M., Niemiecka polityka archiwalna na ziemiach polskich włączonych do Rzeszy 1939-1945, Warszawa-Łódź 1991.

Stebelski A., Losy archiwów polskich w latach wojny 1939-1945, „Rocznik Warszawski” 1963, t. 4.

Śmigiel K., Losy archiwów, bibliotek i muzeów kościelnych pod rządami A. Greisera (1939-1945), "Archiwa, Biblioteki i Muzea Kościelne" 1976, t. 32.

Wojciechowski M., Wojenne losy biblioteki Zygmunta Wojciechowskiego, [w:] Wkregu polityki, dyplomacji i historii XX wieku, red. B. Rakowski, A. Skrzypek, Łódź 2000.

\section{Krzysztof Zawacki}

\section{Archiwum Państwowe w Poznaniu w latach 1939-1945}

\section{Streszczenie}

W niniejszym artykule przedstawiono kwestie związane z organizacją i działalnością Archiwum Państwowego w Poznaniu w latach 1939-1945. W pierwszych akapitach pokazano proces przejmowania poznańskiej placówki przez niemieckie władze archiwalne, do którego należy zaliczyć: zmianę nazewnictwa instytucji na Archiwum Rzeszy w Poznaniu, wymianę kadr, przejęcie kontroli nad państwowym zasobem archiwalnym oraz wprowadzenie systemu opieki archiwalnej. W dalszej części tekstu poruszono wątek związany z zabezpieczeniem i odzyskaniem akt wywiezionych przed rozpoczęciem działań wojennych oraz przejmowaniem dokumentacji instytucji i urzędów, które zakończyły swoją działalność. Niemiecka służba archiwalna interesowała się również archiwaliami kościelnymi, zbiorami prywatnymi oraz aktami zgromadzonymi w archiwach miast i gmin. Poza tym omówiono etapy opracowania materiałów archiwalnych, które nieco odbiegają od współczesnych, a także problemy związane z udostępnianiem dokumentacji archiwalnej.

Słowa kluczowe: Archiwum Państwowe w Poznaniu, Archiwum Rzeszy w Poznaniu, Reichsarchiv, materiały archiwalne, okupacja hitlerowska 
Krzysztof Zawacki

\title{
State Archive in Poznan in the years 1939-1945
}

\begin{abstract}
The article presents the history, organization and operation of the State Archive in Poznan in the years 1939-1945. In the first part, the author describes how German archival organizations took control over the Poznan archive. This process involved several elements: changing the name of the institution to the Reich Archive in Poznań, dismissal of the previous staff, taking control over the state archival fond, and the introduction of a system of archival supervision. Subsequent sections highlight the problem of securing and recovering files removed from the archive before the start of hostilities, as well as collecting documentation belonging to institutions and offices that had been shut down. The German archival service was also interested in church archives, private collections or files collected in the municipal or communal archives. The article also discusses the stages of preparing archival materials, which differ slightly from the modern methods, as well as problems related to accessing and sharing archival documents.
\end{abstract}

Keywords: State Archive in Poznań, Reich Archive in Poznań, Reichsarchiv, archive materials, Nazi occupation 